\title{
UPAYA MENINGKATKAN TANGGUNG JAWAB PESERTA DIDIK PADA PEMBELAJARAN MATEMATIKA MELALUI MODEL KOOPERATIF TIPE JIGSAW DI KELAS VIII A SMP N 2 LENDAH TAHUN PELAJARAN 2018/2019
}

\author{
Nidya Ferry Wulandari ${ }^{1}$, Sutarna ${ }^{2}$ \\ ${ }^{1}$ SMPN 4 Pakem, Sleman, Yogyakarta \\ Jalan Kaliurang KM. 17,5 Pakem, Sleman, Yogyakarta \\ ${ }^{2}$ SMPN 2 Lendah, Kulonprogo, Yogyakarta \\ Ngentakrejo, Lendah, Kulon Progo, 55663 \\ Email: nidyaferry@gmail.com
}

\begin{abstract}
The objective of this study was to improve students' responsibility especially in math class with Jigsaw cooperative learning and to know the implementation Jigsaw in math class. This study was collaboration classroom action research. Kemmis \& Mc. Taggart model was used in this study. The subject of this study was students in eighth grade in SMP N 2 Lendah. The result of this study showed that there is improvement of students' responsibility in math class by using Jigsaw. Students played role as an expert and they discussed specific topic. After that they discussed again in big group and shared what they got in small group. There is 2 cycle because in second cycle has achieved this study target. In last, there is no students have low responsibility or below. Almost $70 \%$ students have high responsibility and the rest have average responsibility.
\end{abstract}

Keywords: responsibility, mathematics, cooperatif model, jigsaw

\section{PENDAHULUAN}

Kualitas pendidikan sering dijadikan sebagai tolok ukur perkembangan suatu negara. Pendidikan menjadi salah satu hal yang penting untuk kemajuan suatu negara. Pendidikan pada dasarnya berorientasi pada pengembangan diri manusia. Pendidikan memiliki peran yang penting dalam mempersiapkan Sumber Daya Manusia (SDM) yang berkualitas dan berkompeten dalam perkembangan ilmu pengetahuan dan teknologi dan untuk kehidupan di masa mendatang.

Banyak faktor yang mempengaruhi kualitas pendidikan di Indonesia, salah satu faktor yang cukup berpengaruh adalah proses pembelajaran itu sendiri. Muijs dan Reynolds menyebutkan bahwa "mathematics as a subject is also strongly influenced by school and classroom effects. The impact of teacher and school on

\footnotetext{
${ }^{1}$ Guru SMP Negeri 4 Pakem, Yogyakarta

${ }^{2}$ Guru SMP Negeri 2 Lendah, Yogyakarta
} 
mathematics outcomes is higher than on English language outcomes" [11]. Pengelolaan kelas dalam proses pembelajaran sangat berdampak pada keberhasilan dan hasil belajar siswa itu sendiri. Metode pembelajaran yang digunakan guru dalam kegiatan pembelajaran akan mempengaruhi hasil pembelajaran. Hal ini serupa dengan yang diungkapkan oleh Rumini bahwa faktor yang berasal dari luar individu siswa seperti guru dan metode mengajar mempengaruhi proses dan hasil belajar siswa [13]. Metode pembelajaran yang melibatkan peran aktif siswa akan semakin menumbuhkan semangat belajar siswa.

Berdasarkan kegiatan prasurvei, proses pembelajaran di SMP N 2 Lendah sudah melibatkan partisipasi aktif siswa melalui kegiatan diskusi kelompok. Guru juga sudah menerapkan 5M dari pendekatan saintifik. Namun, metode pembelajaran diskusi yang dilaksanakan di SMP N 2 Lendah masih belum bervariasi dalam kegiatan diskusi seperti menerapkan berbagai macam model pembelajaran kooperatif. Pembelajaran kooperatif tipe Jigsaw masih jarang diterapkan di SMP N 2 Lendah. Selain itu, berdasarkan hasil observasi ketika pembelajaran dengan diskusi kelompok, masih terdapat siswa yang tidak mengikuti kegiatan diskusi dengan serius dan banyak siswa tidak membawa perlengkapan pembelajaran seperti jangka, penggaris, dan busur seperti yang diperintahkan oleh guru pada pertemuan sebelumnya. Hasil observasi ini diperkuat dengan hasil prasurvei dari angket tanggung jawab belajar yangmenunjukkan bahwa rata-rata tanggung jawab siswa kelas VIII A di SMP N 2 Lendah masih tergolong sedang dan terdapat 6\% siswa memiliki tanggung jawab yang rendah serta 50\% siswa memiliki tanggung jawab sedang.

Berdasarkan amanat Kurikulum 2013, aspek sikap tanggung jawab merupakan salah satu dari karakter sikap sosial yang harus dimiliki peserta didik. Lickona menyatakan bahwa tanggung jawab adalah kesediaan seseorang untuk menerima dan mengerjakan tugas yang menjadi keharusan dengan sebaik-baiknya dalam segala konsekuensi yang menyertainya [10]. Orang yang bertanggung jawab memiliki keyakinan bahwa dirinya memiliki sesuatu yang berharga untuk diberikan kepada orang lain dan yakin bahwa orang lain mampu merasakan hal 
yang sama terhadap dirinya [9]. Sementara itu, Josepshon, dkk. mengungkapkan bahwa tanggung jawab mempunyai beberapa aspek yaitu berani menanggung konsekuensi, kontrol diri, menentukan tujuan dan membuat perencanaan, memilih sifat positif, mandiri, melakukan kewajiban, mencapai hasil yang baik, bersikap proaktif, tekun, dan reflektif [7]. Clemes dan Bean juga menyatakan bahwa remaja yang bertanggung jawab berani untuk mengakui kesalahan tanpa alasan yang dibuat-buat dan mau menanggung konsekuensi dari perbuatannya [4]. Remaja yang bertanggung jawab memiliki kontrol diri yang kuat dan mampu mengatakan tidak pada hal-hal yang dapat merugikan dirinya, dan melakukan hal yang benar [3].

Tanggung jawab dalam belajar adalah kewajiban untuk menyelesaikan tugas yang telah diterima secara tuntas melalui usaha yang maksimal serta berani menanggung segala akibatnya. Taymans menambahkan bahwa sikap bertanggung jawab yang biasa dilatih akan memiliki manfaat diantaranya menjadikan peserta didik proaktif, terlatih untuk membuat keputusan dan tindakan yang benar, membantu dalam mengendalikan situasi, mengetahui solusi terbaik dan tahu kapan solusi digunakan [16]. Selain itu tanggung jawab juga merupakan amanat Kurikulum 2013 untuk kompetensi sikap sosial. Siswa yang memiliki tanggung jawab tentu akan menyelesaikan tugas-tugas belajarnya dengan sungguh-sungguh yang akan mempengaruhi hasil belajar siswa. Oleh karena itu, penting untuk meningkatkan tanggung jawab siswa yang masih rendah.

Setelah melihat proses pembelajaran di kelas, salah upaya yang dapat dilakukan adalah dengan menerapkan suatu model pembelajaran yang memberikan tanggung jawab belajar kepada siswa. Model pembelajaran yang akan diterapkan adalah model pembelajaran kooperatif tipe Jigsaw karena dalam pembelajaran kooperatif tipe Jigsaw siswa belajar secara mandiri baik secara individu maupun kelompok dalam kelompok ahli dan kelompok asal yang dilanjutkan dengan menyajikan hasil belajar di depan kelas akan membuat siswa lebih bertanggung jawab dalam belajar [17]. Sharan menyatakan bahwamodel pembelajaraan kooperatif tipe Jigsaw mengakomodasi peserta didik menjadi ahli dalam mata pelajaran atau subtopik tertentu dan kemudian menyampaikan 
pemahaman akan keahlian tersebut ke kelompok asal mereka [14]. Kauchak \& Eggen juga menegaskan bahwa kegiatan pembelajaran pada Jigsaw dimulai dengan sebuah topik yang dapat dibagi lagi ke dalam suptopik yang lebih kecil [8]. Pemilihan topik pelajaran dalam pembelajaraan kelas tipe Jigsaw dipilihkan oleh guru. Tugas utama peserta didik adalah menganalisis berbagai materi di kelompok ahli dan membantu anggota-anggota di kelompok asal untuk mempelajari berbagai materi. Penilaian yang dilakukan pada kelas kooperatif tipe Jigsaw dapat bervariasi misalnya dapat dilakukan dengan melakukan tes mingguan.

Sementara itu Slavin bahwa dalam Jigsaw para peserta didik bekerja dalam tim yang heterogen [15]. Para peserta didik tersebut diberikan tugas untuk membaca beberapa bab atau unit, dan diberikan "lembar ahli" yang terdiri atas topik-topik yang berbeda yang harus menjadi fokus perhatian masing-masing anggota tim saat mereka membaca. Setelah semua anak selesai membaca, peserta didik-peserta didik dari tim yang berbeda yang mempunyai fokus topik yang sama bertemu dalam "kelompok ahli" untuk mendiskusikan topik mereka sekitar 30 menit. Para ahli tersebut kemudian kembali kepada tim mereka dan secara bergantian mengajari teman satu timnya mengenai topik mereka. Yang terakhir adalah para peserta didik menerima penilaian yang mencakup seluruh topik dan skor kuis akan menjadi skor tim. Skor-skor yang dikontribusikan para peserta didik kepada timnya didasarkan pada sistem skor perkembangan individual dan para peserta didik yang timnya meraih skor tertinggi akan menerima sertifikat atau bentuk-bentuk rekognisi tim lainnya. Sehingga para peserta didik akan termotivasi untuk mempelajari materi dengan baik dan bekerja keras dalam kelompok ahli mereka supaya mereka dapat membantu timnya melakukan tugas dengan baik. Kunci Jigsaw adalah interdependensi yang berarti tiap peserta didik bergantung kepada teman satu timnya untuk dapat memberikan informasi yang diperlukan supaya dapat berkinerja baik saat penilaian.

Dengan melihat permasalahan yang terjadi di kelas VIII A dan berdasarkan ulasan di atas, pada penelitian tindakan kelas ini peneliti tertarik melakukan penelitian yang berjudul "Upaya Meningkatkan Tanggung Jawab Belajar Melalui 
Model Pembelajaran Kooperatif Tipe Jigsaw di Kelas VIIIA SMP N 2 Lendah Tahun Pelajaran 2018/2019".

\section{METODE}

Jenis penelitian yang dilakukan adalah penelitian tindakan kelas secara kolaboratif antara guru mata pelajaran matematika dan praktikan mahasiswa PPG. Peran praktikan mahasiswa PPG disini adalah sebagai perancang dan guru yang mengajar atau praktisi pembelajaran, sedangkan guru mata pelajaran sebagai pengamat atau observer. Penelitian ini dilaksanakan untuk beberapa siklus sampai indikator keberhasilan tercapai, yaitu kurang dari 30\% siswa memiliki tanggung jawab belajar dalam kategori sedang dan lebih dari 70\% siswa memiliki tanggung jawab tinggi atau sangat tinggi.

Waktu penelitian ini direncanakan pada bulan Agustus sampai bulan Oktober 2018 yaitu mulai tanggal 21 Agustus sampai dengan tanggal 2 Oktober 2018. Subjek penelitian ini adalah seluruh siswa kelas VIII A SMP N 2 Lendah yang berjumlah 34 siswa. Dari 32 siswa, 18 siswa berjenis kelamin laki-laki dan 16 siswa berjenis kelamin perempuan.

Penelitian ini direncanakan dalam beberapa siklus sampai memenuhi indikator keberhasilan yang telah ditetapkan, jika belum memenuhi indikator keberhasilan yang ditetapkan maka dilanjutkan untuk siklus berikutnya. Penjabaran kegiatan siklus I yaitu tahap perencanaan, pelaksanaan tindakan, observasi, dan refleksi. Apabila pada hasil refleksi pada siklus I menunjukkan belum mencapai indikator keberhasilan pembelajaran yang sudah ditetapkan maka siklus dilanjutkan ke siklus selanjutnya, dan sebaliknya apabila refleksi pada siklus I sudah mencapai indikator keberhasilan pembelajaran maka siklus akan dihentikan. Berdasarkan hasil refleksi dari siklus I ditentukan perbaikan-perbaikan yang perlu dilakukan pada siklus II yang diimplementasikan pada tahap perencanaan yang terevisi atau yang sudah diperbaiki. Kegiatan-kegiatan yang dilakukan pada siklus II bertujuan untuk memperbaiki kekurangan saat pelaksanaan pembelajaran pada sikuls I.

Teknik pengumpulan data yang digunakan dalam penelitian ini adalah observasi, angket, dan tes. Instrumen yang digunakan dalam penelitian ini adalah 
lembar observasi, angket, dan soal tes tertulis. Adapun untuk analisis data hasil observasi diperoleh dari lembar observasi tentang keterlaksanaan model pembelajaran kooperatif tipe Jigsaw yang dilakukan observer. Jumlah skor total yang diperoleh dari observer pada setiap aspek yang diamati yaitu kegiatan guru dan kegiatan siswa. Setelah dihitung persentase keterlaksanaan pembelajaran, persentase tersebut dikualifikasikan sebagai berikut [1] [6].

Tabel 1. Kualifikasi Keterlaksanaan Pembelajaran

\begin{tabular}{cc}
\hline Persentase keterlaksanaan & Kualifikasi \\
\hline$P>85 \%$ & Sangat tinggi \\
$80 \%<P \leq 85 \%$ & Tinggi \\
$75 \%<P \leq 80 \%$ & Sedang \\
$60 \%<P \leq 75 \%$ & Rendah \\
$P \leq 60 \%$ & Sangat rendah \\
\hline
\end{tabular}

Sementara itu untuk penyekoran angket tanggung jawab belajar siswa dalam penelitian ini memiliki rentang antara 30 sampai 150. Untuk menentukan kriteria hasil pengukurannya diklasifikasikan berdasarkan rata-rata ideal $\left(M_{i}\right)$ dan standar baku ideal $\left(S B_{i}\right) . M_{i}=\frac{1}{2} \times(30+150)=90$ dan $S B_{i}=\frac{1}{6} \times(150-30)=20$. Kategorisasi hasil pengukuran menggunakan kriteria seperti yang dapat dilihat dalam tabel berikut [2].

Tabel 2. Kualifikasi Tanggung Jawab Belajar

\begin{tabular}{ccc}
\hline Interval Skor & Skor $(\mathbf{X})$ & Kategori \\
\hline$X>M_{i}+1,5 S B_{i}$ & $X>120$ & Sangat tinggi \\
$M_{i}+0,5 S B_{i}<X \leq M_{i}+1,5 S B_{i}$ & $100<X \leq 120$ & Tinggi \\
$M_{i}-0,5 S B_{i}<X \leq M_{i}+0,5 S B_{i}$ & $80<X \leq 100$ & Cukup \\
$M_{i}-1,5 S B_{i}<X \leq M_{i}-0,5 S B_{i}$ & $60<X \leq 80$ & Rendah \\
$X \leq M_{i}-1,5 S B_{i}$ & $X \leq 60$ & Sangat Rendah \\
\hline
\end{tabular}

Setelah memperoleh data pengukuran tanggung jawab belajar, total skor masing-masing unit dikategorikan berdasarkan pada kriteria pada tabel di atas. Penelitian dikatakan berhasil jika kurang dari 30\% siswa mempunyai tanggung jawab dalam kategori sedang, dan lebih dari $70 \%$ siswa mempunyai tanggung jawab dalam kategori tinggi atau sangat tinggi dan jika keterlaksanaan pembelajaran matematika dengan model pembelajaran kooperatif tipe Jigsaw lebih dari $85 \%$ terlaksana. 


\section{HASIL DAN PEMBAHASAN}

Kompetensi dasar yang dicapai pada siklus 1 adalah KD 3.2 yaitu kompetensi menjelaskan kedudukan titik dalam bidang Koordinat Kartesius yang dihubungkan dengan masalah kontekstual dan KD 4.2. menyelesaikan masalah yang berkaitan dengan kedudukan titik dalam bidang koordinat Kartesius. Pelaksanaan pembelajaran melalui kegiatan diskusi ahli yang dilakukan setiap individu. Kegiatan ini menuntut peserta lebih bertanggung jawab dalam menyelesaikan LKPD yang diberikan sebagai ahli materi tertentu. Pembagian anggota tim ahli memerlukan intervensi dari guru agar dalam diskusi ahli muncul kelompok homogen yang beranggotakan peserta didik dengan kemampuan rendah. Adanya kuis individu yang dijadikan nilai kelompok membuat peserta didik semakin serius dalam diskusi kelompok. Hal ini sangat memberikan kontribusi dalam meningkatkan tanggung jawab belajar peserta didik

Kegiatan observasi yang dilakukan oleh guru pamong selama pembelajaran menghasilkan data keterlaksanaan pembelajaran seperti pada tabel berikut.

Tabel 3. Keterlaksanaan Pembelajaran Jigsaw Siklus I

\begin{tabular}{ccccc}
\hline Kriteria & $\begin{array}{c}\text { Pertemuan } \\
\text { ke- }\end{array}$ & $\begin{array}{c}\text { Kegiatan } \\
\text { guru }\end{array}$ & $\begin{array}{c}\text { Kegiatan } \\
\text { siswa }\end{array}$ & $\begin{array}{c}\text { Rata-rata \% } \\
\text { keterlaksanaan } \\
\text { pembelajaran }\end{array}$ \\
\hline Terlaksana & 1 & $88 \%$ & $88 \%$ & $88 \%$ \\
$\geq 85 \%$ & 2 & $96 \%$ & $76 \%$ & $86 \%$ \\
& 3 & $88 \%$ & $88 \%$ & $88 \%$ \\
& 4 & $92 \%$ & $92 \%$ & $92 \%$ \\
\hline
\end{tabular}

Berdasarkan tabel keterlaksanaan pembelajaran di atas, baik keterlaksanaan pembelajaran matematika dengan model pembelajaran kooperatif tipe jigsaw di kelas VIII A SMP N 2 Lendah sudah memenuhi indikator keberhasilan, yaitu ratarata keterlaksanaan pembelajaran minimal sebesar $85 \%$. Berikut data hasil angket siswa pada pratindakan dan pada siklus I.

Tabel 4. Hasil Angket Tanggung Jawab Belajar Peserta Didik pada Pratindakan Siklus I

\begin{tabular}{ccccccc}
\hline \multirow{2}{*}{ Skala } & Kualifikasi & $\begin{array}{c}\text { Kondisi Awal } \\
\text { Banyak }\end{array}$ & $\%$ & \multicolumn{2}{c}{ Kriteria } & \multicolumn{2}{c}{ Siklus I } \\
& Siswa & $\%$ & & Banyak & $\%$ \\
\hline$X \geq 120$ & Sangat tinggi & 1 & $3 \%$ & $>70 \%$ & 2 & $6 \%$ \\
$100<X \leq 120$ & Tinggi & 14 & $41 \%$ & & 19 & $56 \%$
\end{tabular}




\begin{tabular}{ccccccc}
\hline Skala & Kualifikasi & \multicolumn{2}{c}{ Kondisi Awal } & \multicolumn{2}{c}{ Kriteria } & \multicolumn{2}{c}{ Siklus I } \\
Banyak & Banyak & Keberhasilan & Siswa & $\%$ \\
\hline $80<X \leq 100$ & Siswa & $\%$ & & & 13 & $38 \%$ \\
$60<X \leq 80$ & Redang & 17 & $50 \%$ & $<30 \%$ & 0 & $0 \%$ \\
$X \leq 60$ & Sangat Rendah & 0 & $0 \%$ & - & 0 & $0 \%$ \\
& Rata-rata & Skor 98 & & Skor 103 \\
& & (Sedang) & & (Tinggi) \\
\hline
\end{tabular}

Berdasarkan pada Tabel 4, terdapat peningkatan tanggung jawab belajar peserta didik dengan diterapkannya model pembelajaran kooperatif tipe Jigsaw pada siklus I. Secara keseluruhan, tanggung jawab peserta didik kelas VIII A meningkat dari rata-rata 98 yang termasuk kategori sedang menjadi 103 dalam kategori tinggi. Selain itu, peningkatan tanggung jawab belajar peserta didik kelas VIII A SMP Negeri 2 Lendah dengan model pembelajaran kooperatif tipe Jigsaw dapat dilihat dari adanya peningkatan persentase peserta didik yang mempunyai tanggung jawab dalam kategori sangat tinggi dari pratindakan sebesar 3\% dan pada siklus I sebesar $6 \%$, sedangkan persentase banyaknya siswa yang mempunyai tanggung jawab tinggi dari pratindakan sebesar $41 \%$ dan pada siklus I sebesar 56\%. Peningkatan persentase siswa yang memiliki tanggung jawab sedang dari pratindakan sebesar 50\% dan siklus I sebesar 38\%.

Dari hasil data pengamatan di kelas yang terkumpulkan selama kegiatan pembelajaran matematika dengan model pembelajaran kooperatif tipe Jigsaw muncul beberapa permasalahan yaitu (1) pengaturan waktu dalam perpindahan kelompok asal ke kelompok ahli dan kembali lagi ke kelompok asal tidak efektif dikarenakan guru harus mengulang-ulang instruksi letak diskusi kelompok asal dan kelompok ahli, (2) anggota kelompok ahli kurang merata yaitu ada satu kelompok ahli yang semua anggota memiliki kemampuan rendah dikarenakan guru tidak melakukan intervensi penentuan pembagian tim ahli, sehingga diskusi pada kelompok ahli menjadi kurang aktif dan perlu banyak bimbingan guru, (3) tidak semua peserta didik dalam kelompok ikut berkontribusi dalam kegiatan diskusi membahas dan menyelesaian LKPD dan hanya menyalin jawaban LKPD ahli dari teman satu kelompoknya, (4) kelompok peserta didik belum menyelesaikan LKPD ahli tepat waktu, sehingga ada rencana kegiatan pembelajaran yang tidak terlaksana pada pertemuan pertama yaitu kuis dan 
rekognisi tim, dan (5) peserta didik enggan untuk melakukan presentasi kelompok di depan kelas.

Melihat permasalahan yang ada dalam siklus I, maka diperlukan beberapa perbaikan agar pelaksanaan dan tanggung jawab peserta didik semakin meningkat. Oleh karena itu perbaikan yang diperlukan yaitu (1) penayangan daftar nama kelompok asal dan denah kelompok asal dan kelompok ahli, karena dengan adanya penayangan daftar nama kelompok asal dan denah kelompok asal dan kelompok ahli peserta didik dapat langsung melihat tayangan LCD untuk melihat anggota dan denah kelompok asal dan kelompok ahli, (2) penentuan anggota kelompok ahli oleh guru yaitu bahwa guru perlu juga melakukan intervensi dalam penentuan atau pembagian ahli dalam setiap kelompok asal sehingga tidak lagi terjadi satu kelompok ahli yang homogen beranggotakan peserta didik berkemampuan kurang, (3) Penilaian kuis individu dengan nilai setiap anggota kelompok diambilkan dari nilai terendah anggota kelompok sehingga akan mengurangi peserta didik dalam kelompok yang tidak ikut berkontribusi dalam kegiatan diskusi hanya menyalin jawaban LKPD ahli dari teman satu kelompoknya, (4) perbaikan LKPD kelompok asal dengan menambahkan pemberian panduan dan tempat dalam LKPD untuk setiap ahli menyampaikan hasil diskusi ahlinya, (5) pemberian batasan waktu diksusi.

Kegiatan pada siklus II merupakan hasil dari refleksi terhadap siklus I. hal ini meliputi kegiatan perencanaan, tindakan dan observasi, dan refleksi. Kegiatan pembelajaran siklus II terdiri dari 5 pertemuan. Kompetensi pengetahuan yang akan dicapai pada siklus II ini adalah KD 3.3. mendeskripsikan dan menyatakan relasi dan fungsi dengan menggunakan berbagai representasi (kata-kata, tabel, grafik, diagram, dan persamaan) dan untuk kompetensi keterampilan pada $\mathrm{KD}$ 4.3. menyelesaikan masalah yang berkaitan dengan relasi dan fungsi dengan menggunakan berbagai representasi. Hasil analisis data hasil observasi pembelajaran seperti pada tabel berikut. 
Tabel 5. Keterlaksanaan Pembelajaran Jigsaw Siklus II

\begin{tabular}{ccccc}
\hline Kriteria & $\begin{array}{c}\text { Pertemuan } \\
\text { ke- }\end{array}$ & $\begin{array}{c}\text { Kegiatan } \\
\text { guru }\end{array}$ & $\begin{array}{c}\text { Kegiatan } \\
\text { siswa }\end{array}$ & $\begin{array}{c}\text { Rata-rata \% } \\
\text { keterlaksanaan } \\
\text { pembelajaran }\end{array}$ \\
\hline Terlaksana & 1 & $92 \%$ & $88 \%$ & $90 \%$ \\
$\geq 85 \%$ & 3 & $96 \%$ & $92 \%$ & $94 \%$ \\
& 4 & $92 \%$ & $92 \%$ & $92 \%$ \\
& 5 & $88 \%$ & $88 \%$ & $88 \%$ \\
& Rata-Rata & $84 \%$ & $86 \%$ \\
\hline
\end{tabular}

Berdasarkan tabel keterlaksanaan pembelajaran di atas, baik keterlaksanaan pembelajaran matematika dengan model Jigsaw di kelas VIII A SMP N 2 Lendah sudah memenuhi indikator keberhasilan, yaitu rata-rata keterlaksanaan pembelajaran minimal sebesar $85 \%$ dan pada siklus II sudah tercapai $90 \%$ keterlaksanaan pembelajaran dengan model Jigsaw. Terdapat peningkatan keterlaksanaan pembelajaran matematika dengan model Jigsaw dari siklus I sebesar $88 \%$ terlaksana dan siklus II $90 \%$ terlaksana. Berikut data hasil angket siswa pada pratindakan dan pada siklus II.

Tabel 6. Hasil Angket Tanggung Jawab Peserta Didik pada Pratindakan-Siklus II

\begin{tabular}{|c|c|c|c|c|c|c|c|c|}
\hline \multirow{2}{*}{ Skala } & \multirow{2}{*}{ Kualifikasi } & \multicolumn{2}{|l|}{$\begin{array}{c}\text { Kondisi } \\
\text { Awal }\end{array}$} & \multirow{2}{*}{$\begin{array}{c}\text { Kriteria } \\
\text { Keberhasilan }\end{array}$} & \multicolumn{2}{|l|}{ Siklus I } & \multicolumn{2}{|l|}{$\begin{array}{c}\text { Siklus } \\
\text { II }\end{array}$} \\
\hline & & $\begin{array}{c}\text { Banyak } \\
\text { Siswa }\end{array}$ & $\%$ & & $\begin{array}{c}\text { Banyak } \\
\text { Siswa }\end{array}$ & $\%$ & $\begin{array}{c}\text { Banyak } \\
\text { Siswa }\end{array}$ & $\%$ \\
\hline$X \geq 120$ & $\begin{array}{c}\text { Sangat } \\
\text { tinggi }\end{array}$ & 1 & $3 \%$ & \multirow{2}{*}{$>70 \%$} & 2 & $6 \%$ & 3 & $9 \%$ \\
\hline $\begin{array}{l}100<X \\
\leq 120\end{array}$ & Tinggi & 14 & $41 \%$ & & 19 & $56 \%$ & 22 & $65 \%$ \\
\hline $\begin{array}{l}80<X \\
\leq 100\end{array}$ & Sedang & 17 & $50 \%$ & $<30 \%$ & 13 & $38 \%$ & 9 & $26 \%$ \\
\hline $60<X \leq 80$ & Rendah & 2 & $6 \%$ & - & 0 & $0 \%$ & 0 & $0 \%$ \\
\hline \multirow[t]{2}{*}{$X \leq 60$} & $\begin{array}{l}\text { Sangat } \\
\text { Rendah }\end{array}$ & 0 & $0 \%$ & - & 0 & $0 \%$ & 0 & $0 \%$ \\
\hline & Rata-rata & \multicolumn{2}{|c|}{$\begin{array}{c}\text { Sedang } \\
\text { (Skor 98) }\end{array}$} & & \multicolumn{2}{|c|}{$\begin{array}{c}\text { Tinggi } \\
\text { (Skor 103) }\end{array}$} & \multicolumn{2}{|c|}{$\begin{array}{c}\text { Tinggi } \\
\text { (Skor 107) }\end{array}$} \\
\hline
\end{tabular}

Dari hasil analisis angket tanggung jawab peserta didik, terlihat bahwa pada siklus II tanggung jawab peserta didik sudah mencapai indikator keberhasilan sehingga penelitian tidak dilanjutkan ke siklus berikutnya. Sementara itu hasil refleksi pada siklus II adalah (1) peserta didik lebih mampu menyelesaikan LKPD tepat waktu, meskipun masih ada anggota kelompok yang kurang aktif aktif dalam berdiskusi menyelesaikan LKPD dan kalaupun ada kegiatan pembelajaran yang 
tidak terlaksana hal itu dikarenakan pengorganisasian waktu, (2) semua peserta didik lebih antusias dalam mengikuti pembelajaran tercermin dari hasil angket tanggung jawab yang telah melampaui indikator keberhasilan, (3) anggota kelompok ahli sudah merata atau tidak ada kelompok ahli yang anggotanya berkemampuan rendah semua, dan (3) peserta didik masih kurang aktif untuk melakukan presentasi kelompok di depan kelas.

Berdasarkan hasil refleksi siklus II ini, tanggung jawab peserta didik secara keseluruhan sudah mengalami peningkatan dan mencapai target yang ditentukan peneliti yaitu sudah kurang dari target 30\% siswa memiliki tanggung jawab sedang dan lebih dari $70 \%$ siswa memiliki tanggung jawab tinggi atau sangat tinggi. Selain itu, keterlaksanaan pembelajaran matematika dengan model Jigsaw sudah mencapai target yang ditetapkan yaitu terlaksana lebih dari $85 \%$. Dengan demikian, pelaksanaan alur siklus penelitian dapat dihentikan pada siklus II.

Berdasarkan deskripsi hasil penelitian yang telah diuraikan, model pembelajaraan kooperatif tipe Jigsaw mengakomodasi peserta didik menjadi ahli dalam mata pelajaran atau subtopik tertentu dan kemudian menyampaikan pemahaman akan keahlian tersebut ke kelompok asal mereka [14]. Begitu pula penerapan model pembelajaran Jigsaw di kelas VIIIA SMP Negeri 2 Lendah menjadikan peserta didik lebih aktif dan saling menyampaikan pendapat. Suasana belajar lebih kondusif, baru dan adanya penghargaan yang diberikan pada kelompok, maka peserta didik dalam setiap kelompok berkompetisi untuk mencapai prestasi yang baik. Respon peserta didik ketika guru mengajar tidak menerapkan model Jigsaw pada pembelajaran matematika di luar penelitian ini, peserta didik minta untuk kerja kelompok ahli dan kuis.

Pada pelaksanaan pembelajaran Jigsaw di kelas VIII A, peserta didik diberikan LKPD ahli agar masing-masing peserta didik merasa bertanggung jawab dengan ahlinya masing-masing. Selain itu, LKPD ahli dijadikan panduan dalam diskusi kelompok ahli. Hal ini sesuai dengan yang dikemukakan oleh Slavin bahwa peserta didik dalam Jigsaw diberikan tugas untuk membaca beberapa bab atau unit, dan diberikan "lembar ahli" yang terdiri atas topik-topik yang berbeda yang harus menjadi fokus perhatian masing-masing anggota tim saat mereka 
membaca [15].

Selain itu, adanya kelompok asal yang beranggotakan 4-5 orang siswa yang berkemampuan heterogen akan membantu mengatasi permasalahan kesulitan dalam belajar matematika di kalangan para siswa dan sebagai tempat untuk menyampaikan hasil diskusi kelompok ahli yang menjadi tanggung jawabnya. Pembiasaan siswa untuk lebih bertanggung jawab akan memicu para siswa untuk mau tidak mau belajar lebih giat lagi.

Pembelajaran dengan menggunakan model Jigsaw, peserta didik akan semakin bertanggung jawab karena peserta didik belajar secara mandiri maupun dalam kelompok ahli dan kelompok asal serta berbagi materi yang dipelajarinya. Lickona menyampaikan bahwa tanggung jawab adalah kesediaan seseorang untuk menerima dan mengerjakan tugas yang menjadi keharusan dengan sebaik-baiknya dalam segala konsekuensi yang menyertainya [10]. Selain itu, tanggung jawab yang dimiliki peserta didik sangat berperan dalam proses belajar dan pembelajaran. Taymans menambahkan bahwa sikap bertanggung jawab yang biasa dilatih akan memiliki manfaat diantaranya menjadikan peserta didik proaktif, terlatih untuk membuat keputusan dan tindakan yang benar, membantu dalam mengendalikan situasi, mengetahui solusi terbaik dan tahu kapan solusi digunakan [16].

Langkah pertama dalam pembelajaran jigsaw yaitu peserta didik diberikan tugas untuk membaca beberapa bab atau unit, dan diberikan "lembar ahli" yang terdiri atas topik-topik yang berbeda yang harus menjadi fokus perhatian masingmasing anggota tim. Ketika membaca atau belajar mandiri ini setiap peserta didik menyiapkan diri untuk siap ikut serta dalam diskusi ahli. Hal ini sesuai dengan yang dikemukakan Donaldson bahwa siswa belajar secara mandiri baik secara individu maupun bekerja kelompok dilanjutkan dengan menyajikan hasil belajar di depan kelas akan membuat siswa lebih bertanggung jawab dalam memecahkan masalah dan keterampilan matematika [5]. Hal ini sesuai dengan salah satu indikator tanggung jawab yaitu mandiri.

Namun, kenyataan di lapangan bahwa dalam belajar mandiri atau tahap membaca peserta didik banyak mengalami kesulitan dan membutuhkan waktu 
yang lama. Oleh karena itu, Jigsaw mengakomodasi peserta didik untuk diskusi dalam kelompok ahli. Diskusi kelompok ahli menjembatani peserta didik untuk saling berbagi materi dengan temannya. Diskusi kelompok ahli ini juga memberikan sebuah tanggung jawab yang dipikul setiap peserta didik untuk disampaikan kepada teman lain di kelompok asal. Langkah selanjutnya dari pembelajaran Jigsaw adalah laporan tim ke kelompok asal. Seperti dikutip dari O’Neill bahwa berkontribusi dalam kegiatan yang melibatkan orang lain dapat menunjukkan sikap tanggung jawab peserta didik [12].

Adapun peningkatan tanggung jawab peserta didik kelas VIII A SMP Negeri 2 Lendah dengan diimplikasikannya model pembelajaran Jigsaw dapat dilihat dalam penyajian diagram sebagai berikut.

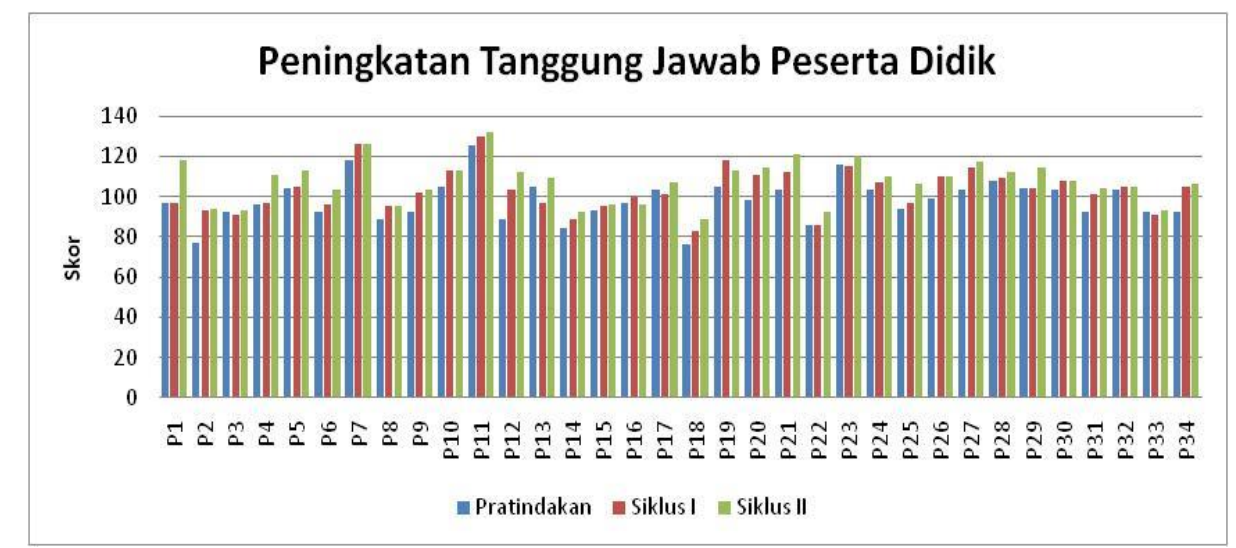

Gambar 1. Diagram Peningkatan Tanggung Jawab Setiap Peserta Didik

Dari diagram di atas dapat diketahui bahwa dari 34 siswa, tanggung jawab sebagian besar siswa meningkat mulai pratindakan sampai siklus II berakhir, walaupun ada beberapa siswa yang tanggung jawabnya tetap dan bahkan ada yang mengalami penurunan yang tidak signifikan. Jika peningkatan tanggung jawa siswa dilihat secara klasikal dari pratindakan sampai siklus II maka terlihat seperti pada diagram berikut: 


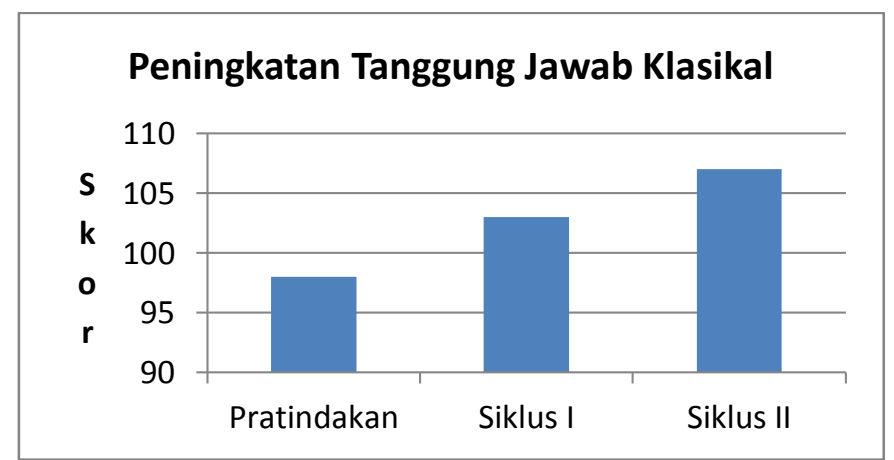

Gambar 2. Diagram Peningkatan Tanggung Jawab Siswa secara Klasikal

Dari diagram di atas dapat diketahui secara jelas bahwa tanggung jawab peserta didik kelas VIII A SMP Negeri 2 Lendah meningkat dari pratindakan sampai pada akhir siklus II dengan diterapkannya model pembelajaran kooperatif Jigsaw. Di samping terlihat dari hasil peningkatan dan ketercapaian tanggung jawab peserta didik, keberhasilan penelitian dikarenakan juga adanya peningkatan terhadap proses pembelajaran matematika di kelas VIII A dari siklus I ke siklus II. Oleh karena itu, secara umum dapat disimpulkan bahwa tanggung jawab peserta didik kelas VIII A SMP Negeri 2 Lendah meningkat dan mencapai indikator keberhasilan yaitu kurang dari sepertiga banyak siswa yang memiliki tanggung jawab sedang, sedangkan yang lainnya memiliki tanggung jawab tinggi atau sangat tinggi serta pelaksanaan pembelajaran dengan model Jigsaw meningkat dan terlaksana lebih dari $85 \%$ dari rencana kegiatan yang dibuat.

\section{KESIMPULAN}

Berdasarkan hasil penelitian, pembahasan, dan refleksi maka dapat diambil beberapa kesimpulan yaitu pelaksanaan pembelajaran matematika dengan model pembelajaran kooperatif tipe Jigsaw dalam meningkatkan tanggung jawab peserta didik kelas VIII A SMP Negeri 2 Lendah adalah sebagai berikut:

a. Melalui kegiatan diskusi ahli yang dilakukan setiap individu menuntut peserta lebih bertanggung jawab dalam menyelesaikan LKPD yang diberikan sebagai ahli materi tertentu.

b. Pembagian anggota tim ahli yang memerlukan intervensi dari guru agar dalam diskusi ahli muncul kelompok homogen yang peserta didik masih kurang berkompeten. 
c. Adanya kuis individu yang dijadikan nilai kelompok membuat peserta didik semakin serius dalam diskusi kelompok. Hal ini sangat memberikan kontribusi dalam meningkatkan tanggung jawab belajar peserta didik

\section{DAFTAR PUSTAKA}

[1] S. Arikunto, Suhardjono, \& Supardi, Penelitian tindakan kelas, Jakarta: Bumi Aksara, 2006.

[2] S. Azwar, Penyusunan skala psikologi, Yogyakarta: Pustaka Pelajar, 2010.

[3] M. Borba, Membangun Kecerdasan Moral, Jakarta: Gramedia Pustaka Utama, 2008.

[4] H. Clemes \& R. Bean, Melatih Anak Bertanggung Jawab (Terjemahan), Jakarta: Mitra Utama, 2001.

[5] G. H. C. Donaldson, Learning Together: Mathematics: Research Report by HMIE on Inspection and Review 2005-2008, 2009.

[6] L. R. Ebel \& D. A. Frisbie, Essentials of Educational Measurement $5^{\text {th }}$ edition, New Jersey: Prentice-Hall, Inc., 1991

[7] M. S. Josepshon, V. J. Peter, \& T. Dowd, Menumbuhkan 6 Sikap Remaja Idaman, Jakarta: Kaifa, 2003.

[8] D. P. Kauchak \& P. D. Eggen, Learning And Teaching : Research Based Methods, Massachusetts, MA: Allyn and Bacon, 1989.

[9] B. A. Lewis, Character Building untuk Remaja, Batam: Kharisma Publishing Group, 2004.

[10] T. Lickona, Mendidik untuk Membentuk Karakter Bagaimana Sekolah dapat Memberikan Pendidikan tentang Sikap Hormat dan Tanggung Jawab. Penerjemah: Juma Abdu Wamaungo. Jakarta: PT Bumi Aksara, 2012.

[11] D. Muijs \& D. Reynolds, Effective teaching: evidence and practice $\left.2^{\text {nd }} e d\right)$, London, UK: Sage Publications Ltd, 2011.

[12] N. O'Neil, Promising Practices For Personal And Social Responsibility: Finding From a Nationa Research Collaborative. Assosiation of American Colleges and Universities: John Templeton Foundation. http://www.aacu.org/sites/default/files/files/core_commitments/promising_p r actices_rc2012.pdf. (diakses 31 Januari 2015).

[13] S. Rumini, dkk., Psikologi Pendidikan, Yogyakarta: Unit Percetakan dan Penerbitan (UPP) Universitas Negeri Yogyakarta, 1995

[14] S. Sharan, Handbook Of Coorperative Learning (Terjemahan), Yogyakarta: Imperium, 2009.

[15] R. Slavin, Cooperative Learning: Teori, Riset dan Praktik, Bandung: Nusa Media, 2008.

[16] J. M. Taymans, Learningto Achieve: A Professional's Guide to Educating Adults with Learning Disabilities, Washington: National Institute for Literacy, 2010.

[17] Wardani, dkk., Penelitian Tindakan Kelas, Jakarta: Universitas Terbuka, 2002. 